\title{
RHEUMATIC DISEASES IN DENMARK
}

BY

\author{
K. KALBAK \\ From the National Danish Association against Rheumatic Diseases, Copenhagen, Denmark
}

(RECEIVED FOR PUBLICATION OCTOBER 8, 1953)

In 1946 The National Danish Association against Rheumatic Diseases and The Danish Society for Rheumatology in co-operation with Dansk Gallup Institut conducted a general investigation into the number and nature of rheumatic diseases in the population of Denmark.

Denmark proper, with an area of 42,931 sq. kilometres and a population of about 4 millions, lies in Northern Europe between Lat. $57 \cdot 7^{\circ}$ and $54 \cdot 6^{\circ} \mathrm{N}$. and Long. $8 \cdot 1^{\circ}$ and $15 \cdot 2^{\circ} \mathrm{E}$. The climate is temperate. The mean temperature is approximately $0^{\circ} \mathrm{C}$. in January and $16-17^{\circ} \mathrm{C}$. in July. The prevailing winds are westerly. Annual precipitation varies from 45 to $80 \mathrm{~cm}$., and the annual number of days of precipitation from 118 to 192.

A country like this is especially suited for an investigation of this nature; it is homogeneous in regard to population, geography, climate, and sanitary and social conditions, and the compulsory notification of diseases is quite comprehensive. Moreover, communications are so good that the country can be covered by a relatively small number of investigators within a very short time. Hospital reports are extensive, and afford good and accurate information, and, owing to the uniform tuition and frequent professional contact between doctors, standards of diagnosis also tend to be uniform.

\section{Material}

The investigation covered the whole population of $\stackrel{\circ}{工}$ Denmark over 6 years of age, a total of $3,660,000$ persons. The patients concerned were divided into three groups:
(A) In-patients.
(B) Disabled patients (receiving public aid).
(C) Out-patients.

The three main subjects of inquiry were:

(1) What is the number of patients?

(2) What rheumatic diseases occur, and what is the distribution?

(3) What do these diseases cost the community int treatment and loss of wages?

The rheumatic diseases were arranged in a few main groups (Table I) without division in smaller groups where nomenclature might be open to doubt or discussion:

TABLE I

INCIDENCE OF RHEUMATIC DISEASE FROM HOSPITAL RECORDS

\begin{tabular}{|c|c|c|c|c|c|c|c|c|c|c|}
\hline & \multirow{3}{*}{\multicolumn{2}{|c|}{ Type of Rheumatic Disease }} & & & \multicolumn{2}{|c|}{ (A) In-Patients } & \multicolumn{4}{|c|}{ (C) Out-Patients } \\
\hline & & & & & \multirow{2}{*}{ No. } & \multirow{2}{*}{ Per cent. } & \multicolumn{2}{|c|}{ Sex } & \multirow{2}{*}{ No. } & \multirow{2}{*}{ Per cent. } \\
\hline & & & & & & & Women & Men & & \\
\hline \multirow[t]{2}{*}{ I. Articular } & $\begin{array}{l}\text { (1) Rheumatic fever } \\
\text { (2) Rheumatoid arthritis } \\
\text { (3) Spondylosis . } \\
\text { (4) Arthrosis coxae } \\
\text { (5) Arthrosis genu } \\
\text { (6) Other arthroses } \\
\text { (7) Gout . } \\
\text { (8) Other articular rheum }\end{array}$ & $\begin{array}{ll}\ldots & \ldots \\
\cdots & \cdots \\
\ldots & \cdots \\
\cdots & \cdots \\
\ldots & \cdots \\
\cdots & \cdots \\
\text { natic diseases }\end{array}$ & $\begin{array}{l}\cdots \\
\cdots \\
\cdots \\
\cdots \\
\cdots \\
\cdots\end{array}$ & $\begin{array}{l}\cdots \\
\cdots \\
\cdots \\
\cdots \\
\cdots \\
\cdots\end{array}$ & $\begin{array}{r}1,709 \\
2,145 \\
407 \\
543 \\
471 \\
624 \\
167 \\
779\end{array}$ & $\begin{array}{r}14 \\
18 \\
4 \\
5 \\
4 \\
5 \\
1 \\
7\end{array}$ & $\begin{array}{r}3 \\
72 \\
6 \\
68 \\
368 \\
-\quad 3 \\
107\end{array}$ & $\begin{array}{r}3 \\
10 \\
10 \\
37 \\
40 \\
\frac{12}{68}\end{array}$ & $\begin{array}{r}6 \\
82 \\
16 \\
105 \\
408 \\
-15 \\
175\end{array}$ & $\begin{array}{l}0 \cdot 2 \\
2 \cdot \\
0 \cdot 4 \\
2 \cdot 5 \\
9 \cdot 5 \\
\overline{0 \cdot 4} \\
4\end{array}$ \\
\hline & Total & $\ldots$ & $\ldots$ & . & 6,845 & 58 & 627 & 180 & 807 & 19 \\
\hline \multirow[t]{2}{*}{ II. Non-Articular } & $\begin{array}{l}\text { (1) Neck/head } \\
\text { (2) Shoulder/arm ... } \\
\text { (3) Forearm/hand... } \\
\text { (4) Lumbago/sciatica (mo } \\
\text { (5) Leg/foot . } \\
\text { (6) Other non-articular r }\end{array}$ & $\begin{array}{l}\ldots \\
\ldots \\
\ddot{o s t l y} \text { disk diso } \\
\therefore \\
\text { heumatic dise }\end{array}$ & $\begin{array}{l}\ldots \\
\ldots \\
\text { orders) } \\
\text { ases }\end{array}$ & $\begin{array}{l}\cdots \\
\cdots \\
\cdots \\
\cdots \\
\cdots\end{array}$ & $\begin{array}{l}\overline{490} \\
2 \overline{027} \\
2, \overline{571}\end{array}$ & $\frac{\overline{4}}{\frac{16}{22}}$ & $\begin{array}{l}463 \\
605 \\
257 \\
679 \\
276 \\
340\end{array}$ & $\begin{array}{r}100 \\
194 \\
71 \\
324 \\
75 \\
88\end{array}$ & $\begin{array}{r}563 \\
799 \\
328 \\
1,003 \\
351 \\
428\end{array}$ & $\begin{array}{r}13 \\
19 \\
8 \\
23 \\
8 \\
10\end{array}$ \\
\hline & Total & $\ldots$ & $\ldots$ & $\ldots$ & 5,088 & 42 & 2,620 & 852 & 3,472 & 81 \\
\hline
\end{tabular}




\section{Results}

(A) In-Patients.-In 1945, a total of 12,913 patients with various rheumatic diseases were treated in 154 hospital wards and two sanatoria. Of these, 980 were treated at sanatoria; the distribution of the remaining 11,933 hospital patients is shown in Table I (A). The hospitalized patients may be classified as follows, according to the frequency. of the various forms of rheumatic disease:

Type of Rheumatic Disease (see Table I) $\%$

(a) Undefined non-articular diseases, also termed "muscular rheumatism", presumably mostly psychogenic reactions in connexion with neuroses, climacterium, etc. (II, 6) $\quad$. 22

(b) Rheumatoid arthritis (I, 2) $\quad \ldots \quad \ldots \quad \ldots .18$

(c) Degenerative diseases, arthroses (I, 3, 4, 5, $\ddot{6}) \quad 18$

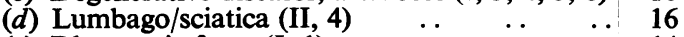

(e) Rheumatic fever $(I, 1) \ldots \quad \ldots \quad \ldots \quad \ldots 14$

$(f)$ Other articular diseases, Reiter's disease, ankylosing spondylitis, etc. (I, 8) . . $\quad$. 74

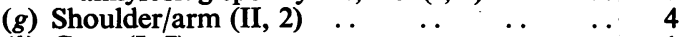

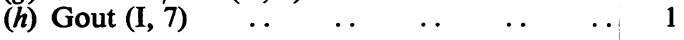

$\begin{array}{lllllll}\text { Total } & \ldots & \ldots & \ldots & \ldots & \ldots & 100\end{array}$

(B) Disabled Patients.-Persons receiving public aid in consequence of a rheumatic disease that had reduced their capacity for work to less than onethird of normal were nearly all suffering from rheumatoid arthritis. The number of totally disabled patients was approximately 3,800 (about 5 per cent. of all the disabled in Denmark). This figure is fairly constant from year to year, the increase and decrease being about equal. The annual increase of new invalids is about 365 , which is as much as to say that every day one person becomes totally disabled by rheumatoid arthritis, the sex ratio being about three women to one man. As a rule, these patients are forced to give up working in about their 45 th year; in other words, they lose about 15 normal working years, and each calendar year the community loses 5,500 working years through their disablement.

(C) Out-Patients.-This group is by far the greatest and also the most difficult to register, but it is possible to obtain a fairly correct picture of conditions in Greater Copenhagen, since about 80 per cent. of the population have access to six special out-patient clinics for rheumatic diseases, which belong to the Cooperative Sickness Insurance Corporations. The reports from these clinics give a fairly accurate picture of the number, nature, and distribution of rheumatic diseases so treated.

A direct registration was made during the last 3 weeks of June, 1946, and in this period, altogether 4,279 patients with various rheumatic diseases were treated. The distribution of the various types of disease is shown in Table $\mathrm{I}(\mathrm{C})$. The out-patients may be classified according to the frequency of the various forms of rheumatic disease as follows:

Type of Rheumatic Disease (see Table I) $\%$

(a) Lumbago/sciatica, prolapsed intervertebral disk, spondylolisthesis, disk degeneration (II, 4) ..

(b) Painful shoulder, brachial neuralgia, scalenus anticus syndrome, etc. (II, 2) .. ..

(c) Neck/head, occipital-syndrome, cephalalgia rheumatica, etc. (II, 1) $\quad$. $\quad \ldots . \quad \ldots \quad 13$

(d) Degenerative articular disease, arthroses

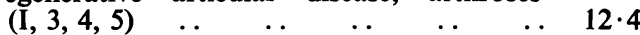

(e) Undefined non-articular disease (II, 6) $\quad \ldots 10$

$(f)$ Forearm/hand, epicondylitis, bursitis, etc.

\begin{tabular}{llll} 
(II, 3) & (g) $\mathrm{Leg} / \mathrm{foot}$, restless legs, fiat feet, etc. (II, 5) $\ldots$ & 8 \\
\hline
\end{tabular}

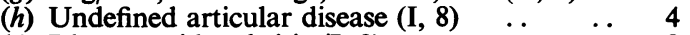

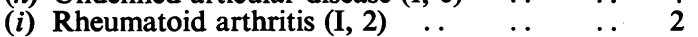

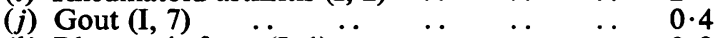

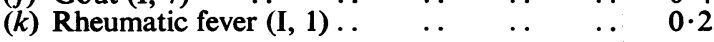

Total

100

The sex ratio is about three women to one man. (Table II).

TABLE II

INCIDENCE OF RHEUMATIC DISEASE BY SEX

\begin{tabular}{|c|c|c|c|c|c|c|}
\hline \multirow{2}{*}{ Sex } & \multicolumn{2}{|c|}{$\begin{array}{c}\text { Articular } \\
\text { Rheumatism }\end{array}$} & \multicolumn{2}{|c|}{$\begin{array}{l}\text { Non-Articular } \\
\text { Rheumatism }\end{array}$} & \multicolumn{2}{|c|}{ Total } \\
\hline & No. & $\%$ & No. & $\%$ & No. & $\%$ \\
\hline Women .. & 627 & 77 & 2,620 & 75 & 3,247 & 76 \\
\hline Men & 180 & 23 & 852 & 25 & 1,032 & 24 \\
\hline Total .. & 807 & 100 & 3,472 & 100 & 4,279 & 100 \\
\hline
\end{tabular}

The total number of patients in Greater Copenhagen applying annually for treatment as outpatients at these special clinics is about 30,000 . To these must be added another 10,000 patients, who, not being contributors of any sick insurance fund, apply to private specialists for similar treatment. Therefore approximately 40,000 patients (out of a total of 820,000 inhabitants over 6 years of age) apply every year for special ambulatory treatment for rheumatic diseases in Greater Copenhagen.

The average duration of treatment is about 40 days. Patients with non-articular disease are on an average sick-listed for 20 days, and patients with articular disease for 40 days. The cost of treatment at the special clinics is about $\$ 6$ per day.

\section{Further General Inquiries}

The figures listed above, however, are far from covering the total number of rheumatic patients in Greater Copenhagen. Many do not apply for special 
treatment, but get along with such medical and physical therapy as their family doctors are able to give them. Outside the city this class of patients is even larger because specialist treatment is more difficult to obtain. Since this group is not registered, other methods must be used to find its size.

It is not compulsory for doctors to notify cases of rheumatic disease, and the only way to find out the number of sufferers was to approach the patients themselves by means of the Gallup system. By investigating a 1 per cent. section of the population that is representative in regard to sex, age, occupation, etc., 98 per cent. accuracy is obtainable, but to be on the safe side we decided to question about 2 per cent. (a total of 5,661 persons out of $2,840,000$ ). The investigation was carried out in June, 1946, by specially trained senior medical students.

The first question was: Have you ever had a rheumatic disease? By means of a system of control questions it could be ascertained whether the diseases complained of were actually recognized rheumatic conditions. It was found that no less than 32 per cent. of the population of Denmark (of 6 years old or over) claimed to suffer from, or have suffered from, a rheumatic disease, and that these diseases occurred most frequently after the age of 45 . There was no geographical or occupational differences of any consequence. At the time of the investigation, $761(13.5$ per cent.) out of the 5,661 persons questioned replied Yes to the question whether they were suffering from rheumatism then.

In the winter, this percentage is somewhat higher (as may be expected); an investigation in the winter season showed that 18 per cent. of the population were then suffering from some rheumatic disease.

It is interesting to observe that similar results have been obtained both in Great Britain (Kellgren and others, 1953) and in the Netherlands (de Blécourt, 1953), in similar investigations, although the methods of registration were different. This fact is strong evidence that our figures are correct (Table III).

TABLE III

COMPARATIVE INCIDENCE OF RHEUMATIC DISEASE IN GREAT BRITAIN, THE NETHERLANDS, AND DENMARK

\begin{tabular}{|c|c|c|c|}
\hline Country & Great Britain & Netherlands & Denmark \\
\hline $\begin{array}{l}\text { Percentage of population } \\
\text { suffering or having suffer- } \\
\text { edfroma rheumaticdisease }\end{array}$ & $33-40$ & 一 & 32 \\
\hline $\begin{array}{l}\text { Percentage of population } \\
\text { suffering from a manifest } \\
\text { rheumatic disease at the } \\
\text { moment of registration... }\end{array}$ & 19 & $15-20$ & $13 \cdot 5-18$ \\
\hline
\end{tabular}

\section{Conclusions}

These figures may serve as basis for a computation of conditions in the whole country; and thence we may calculate the number of sick-days and $\overparen{\Phi}$ the number of working years lost in consequence of 3 rheumatic disease (Table IV).

TABLE IV

TIME LOST THROUGH RHEUMATIC DISEASE (days)

\begin{tabular}{|c|c|c|c|c|}
\hline Patients & $\begin{array}{l}\text { Type of } \\
\text { Rheumatic } \\
\text { Disease }\end{array}$ & $\begin{array}{c}\text { No. } \\
\text { of } \\
\text { Patients }\end{array}$ & $\begin{array}{c}\% \text { of } \\
\text { All } \\
\text { Patients }\end{array}$ & $\begin{array}{l}\text { No. of } \\
\text { Days } \\
\text { Sick }\end{array}$ \\
\hline \multirow[t]{2}{*}{$\begin{array}{l}\text { Out-Patients } \\
\text { (including } \\
\text { Disabled) }\end{array}$} & $\begin{array}{l}\text { Articular } \\
\text { Non-Articular }\end{array}$ & $\begin{array}{l}216,000 \\
339,000\end{array}$ & $\begin{array}{l}40 \\
60\end{array}$ & $\begin{array}{l}4,839,000 \\
1,692,000\end{array}$ \\
\hline & Total & 555,000 & 100 & $6,531,000$ \\
\hline \multirow[t]{2}{*}{ In-Patients } & $\begin{array}{l}\text { Articular } \\
\text { Non-Articular }\end{array}$ & $\begin{array}{l}7,200 \\
4,800\end{array}$ & $\begin{array}{l}60 \\
40\end{array}$ & 420,000 \\
\hline & Total & 12,000 & 100 & 420,000 \\
\hline \multicolumn{2}{|c|}{ Grand Total } & 567,000 & - & $6,951,000$ \\
\hline
\end{tabular}

Seven million sick-days a year means that Den- $\mathscr{\circ}$ mark loses 20,000 working years each calendar 을 year; or, to put it another way, 20,000 persons are idle all the year round because of these diseases.

The rheumatic diseases cost the Danish community $\stackrel{\mathbb{D}}{\varnothing}$ a total of $\$ 25$ million a year in treatment, loss of $\$$ wages, and disablement benefits (Table V).

TABLE $\mathrm{V}$

EXPENSE TO THE COMMUNITY IN TREATMENT, BENEPX PAYMENTS, AND LOSS OF WAGES (Mill. \$)

\begin{tabular}{ll|c|c|c|c}
\hline \multicolumn{1}{c|}{ Patients } & Treatment & $\begin{array}{c}\text { Loss of } \\
\text { Wages }\end{array}$ & $\begin{array}{c}\text { Disablement } \\
\text { Benefits }\end{array}$ & $\begin{array}{c}\text { Total } \\
\text { Cost }\end{array}$ \\
\hline Out-Patients &.. & 1.74 & 15.00 & - & 16.74 \\
\hline In-Patients &. & 1.68 & 1.26 & - & 2.94 \\
\hline Disabled .. &.. & - & 4.16 & 0.76 & 4.92 \\
\hline Total Cost &. & 3.42 & 20.42 & 0.76 & 24.60 \\
\hline
\end{tabular}

\section{Summary}

The results are given of a survey of the incidence of rheumatic disease in Denmark in the year 1946. Hospital records and disability payments were supplemented by questioning a 2 per cent. sample of the whole population of 6 years old and over.

It is estimated that 13.5 to 18 per cent. of the population are suffering from some form of rheumatic disease at any given moment, and that 20,000 N working years and $\$ 25$ million dollars are lost to the nation annually as a result.

\section{REFERENCES}

de Blecourt, J. J. (1953). "Examination of the Population with respect to the Presence of Rheumatism." VIII int. Congr. Rheumatol.,

Genéve, 1953. Médecine et Hygiène, Geneva.
Kellgren, J. H., Lawrence, J. S., and Aitken-Swan, J. (1953). Annals of the Rheumatic Diseases, 12, 5. 
Maladies rhumatismales au Danemark

RÉSUMÉ

On présente les résultats d'une revue de la fréquence des maladies rhumatismales au Danemark en 1946. Des renseignements provenant des dossiers hospitaliers et des fiches de payement de pension d'invalidité furent supplémentés par un questionnaire direct adressé à une section de la population générale représentant 2 pour cent de tous les individus âgés de 6 ans ou plus.

On estime qu'à n'importe quel moment 13,5 pour cent à 18 pour cent de la population est atteint d'une des formes de la maladie rhumatismale et qu'en conséquence 20 mille années de travail et 25 millions de dollars sont perdus annuellement par la nation.

\section{Enfermedades reumáticas en Dinamarca}

Sumario

El autor presenta los resultados de una revista de la incidencia de las enfermedades reumáticas en Dinamarca en 1946. A los informes recogidos en los registros hospitalarios y en las hojas de pago de pensión de invalidez se añadió un cuestionario directo dirigido a una sección de la población entera representando el 2 por ciento de todos los individuos de 6 o más años de edad.

Se estima que en cualquier momento entre el 13,5 por ciento y el 18 por ciento de la población sufre de una de las formas de la enfermedad reumática y que en consecuencia la nación pierde anualmente 20 mil años de trabajo y 25 miliones de dólares. 